\title{
Task Effects in the Interpretation of Pronouns
}

\author{
Sanoudaki, E.; Varlokosta, S.
}

\section{Language Acquisition}

\author{
DOI: \\ 10.1080/10489223.2014.928297
}

Published: 03/06/2014

Peer reviewed version

Cyswllt i'r cyhoeddiad / Link to publication

Dyfyniad o'r fersiwn a gyhoeddwyd / Citation for published version (APA):

Sanoudaki, E., \& Varlokosta, S. (2014). Task Effects in the Interpretation of Pronouns. Language Acquisition, 22(1), 40-67. https://doi.org/10.1080/10489223.2014.928297

\footnotetext{
Hawliau Cyffredinol / General rights

Copyright and moral rights for the publications made accessible in the public portal are retained by the authors and/or other copyright owners and it is a condition of accessing publications that users recognise and abide by the legal requirements associated with these rights.

- Users may download and print one copy of any publication from the public portal for the purpose of private study or research.

- You may not further distribute the material or use it for any profit-making activity or commercial gain

- You may freely distribute the URL identifying the publication in the public portal ?

Take down policy

This is an Accepted Manuscript of an article published by Taylor \& Francis in Language Acquisition in June 2014 available online: http://wwww.tandfonline.com/ DOI http://dx.doi.org/10.1080/10489223.2014.928297

\section{Take down policy}

If you believe that this document breaches copyright please contact us providing details, and we will remove access to the work immediately and investigate your claim.
} 


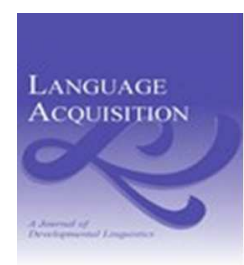

$\Delta=\div-=$

Task effects in the interpretation of pronouns

\begin{tabular}{|r|l|}
\hline Journal: & Language Acquisition: A Journal of Developmental Linguistics \\
\hline Manuscript ID: & HLAC-2012-12-A-0065.R2 \\
\hline Manuscript Type: & Article \\
\hline Keywords: & Anaphora/Binding, Processing \\
\hline \multicolumn{2}{|c}{} \\
\hline
\end{tabular}

SCHOLARONE ${ }^{\mathrm{m}}$

Manuscripts

This is an Accepted Manuscript of an article published by Taylor \& Francis in Language Acquisition in June 2014, available online: http:// wwww.tandfonline.com/ DOI http://dx.doi.org/10.1080/10489223.2014.928297 
INTERPRETATION OF PRONOUNS

1

2

3

4

5

6

7

8

9

10

11

12

13

14

15

16

17

18

19

20

21

22

23

24

25

26

27

28

29

30

31

32

33

34

35

36

37

38

39

40

41

42

43

44

45

46

47

48

49

50

51

52

53

54

55

56

57

58

59

60

Task effects in the interpretation of pronouns 


\begin{abstract}
Children acquiring a range of languages have difficulties in the interpretation of personal pronouns. Ongoing debates in the relevant literature concern the extent to which different pronoun types are subject to this phenomenon, as well as the role of methodology in relevant research. In this study, we use two different experimental tasks to examine the interpretation of pronominal elements in Greek, a language that has both strong pronouns and pronominal clitics. Results reveal a complete absence of problems in the interpretation of clitics irrespective of task. However, there were task effects in the comprehension of strong pronouns in both children and adults. Findings indicate that the phenomenon is intrinsically linked to the properties of the elements in question. Analysis of the task effects highlights how different methodological manipulations can shed light on different properties of the elements studied.
\end{abstract}




\section{Introduction}

The interpretation of pronouns in typical and atypical populations has been the subject of extensive experimentation and intense debate in the last few decades, starting as early as the eighties (e.g. Jakubowicz, 1984; Solan, 1987; Wexler \& Chien, 1985) up to now (e.g. Baauw, Zuckerman, Ruigendijk \& Avrutin, 2011; Conroy, Takahashi, Lidz \& Phillips, 2009; Elbourne, 2005, 2008). The crux of the matter has been the observed cross-linguistic difficulties in the interpretation of personal pronouns by typically developing children. Specifically, typically developing children up to around the age of six sometimes interpret personal pronouns reflexively in a variety of languages (Avrutin \& Wexler, 1992; Baauw, 1999; Chien \& Wexler, 1990; McDaniel, Cairns \& Hsu, 1990; Philip \& Coopmans, 1996; Thornton, 1990, among others). For example, children sometimes interpret a sentence such as (1) as The princess is painting herself. The phenomenon has been called the Delay of Principle B Effect (DPBE), and more recently, the Pronoun Interpretation Problem (PIP; Baauw et al., 2011).

(1) PIP context:

The princess is painting her.

However, numerous studies on the acquisition of pronouns have provided results that appear to be inconsistent with each other (for detailed listings of studies and results see Conroy et al., 2009). Following decades of research and dozens of relevant studies, the possibility that experimental design and choice of experimental 
materials and tasks may radically affect the results has become prominent, and methodology in the study of pronouns is now the subject of fierce debate (e.g. Baauw et al., 2011; Conroy et al., 2009; Elbourne, 2008; Hartman, Sudo \& Wexler, 2012). In this disagreement, two factors affecting children's performance in relevant tasks emerge: a) pragmatic/task considerations (Conroy et al., 2009), b) the type of elements tested, with pronominal clitics possibly being exempt from the PIP (Hartman et al., 2012).

In this study, we aim to explore the interplay of these factors by examining the interpretation of pronominal elements by Greek-speaking children and adults. The choice of language is based on the fact that the few published studies examining the acquisition of Greek pronominal elements have revealed unexpected patterns in the interpretation of these elements (Varlokosta, 2000, 2001a, 2002). We will argue that some of these patterns are linked to the categorical status and properties of the pronominal elements tested. By performing different methodological manipulations, we seek to unravel these patterns, while contributing to the ongoing debate on pronoun interpretation.

\subsection{The PIP}

The PIP, whereby children interpret object pronouns reflexively, has been shown to be active in a variety of languages, including English (Chien \& Wexler, 1990), Russian (Avrutin \& Wexler, 1992), Dutch (Philip \& Coopmans, 1996), Icelandic (Sigurjónsdóttir \& Hyams, 1992), etc. Even though the phenomenon was widely known for a long period of time as the Delay of Principle B Effect, it has not been 
attributed to children's lack of knowledge of Principle B of Binding Theory (Chomsky, 1981, 1986), the identification of object pronouns with local ccommanding antecedents constituting only an apparent violation of the Principle.

However, results provided by different experimental studies testing pronoun interpretation in typically developing children show considerable inconsistency, with the acceptance rate of the anaphoric interpretation differing greatly across studies (for a detailed list of studies and corresponding percentages see Conroy et al., 2009).

The acceptance of the anaphoric interpretation in children has been linked to the fact that local coreference is possible in adult language, in specific contexts, such as (2).

(2) Everyone loves Christopher. John loves him, Mary loves him, even Christopher loves him.

The link between cases of local coreference in adult language and PIP is in line with the theoretical approach which distinguishes pragmatic coreference from syntactic binding: according to Grodzinsky \& Reinhart (1993), a pronoun can corefer with a local antecedent if and only if the resulting interpretation would be distinguishable from a structure involving binding (Rule I, Grodzinsky \& Reinhart, 1993). This is the case in (2) above but not in (1), where adults reject the anaphoric reading. The coreference exemplified in (2) is often called local accidental co-reference: the pronoun 'him' and the noun 'Christopher' are not co-indexed in a bound-variable reading, where the pronoun receives its interpretation from its antecedent (3a), as this would have been ruled out by Principle B. Instead, the pronoun and noun have different indices ( $3 b)$, and they happen to refer to the same entity. 
(3a) Christopher loves $_{\text {him }}$ (bound variable, ruled out by Principle B)

(3b) Christopher loves him $_{\mathrm{k}}$ (local accidental co-reference)

According to this view, the high percentages of anaphoric interpretations are a consequence of children's problems with the pragmatic rule that regulates coreference ${ }^{1}$.

The theoretical account is in line with findings showing that children do not allow anaphoric interpretations of pronouns when the preceding noun is replaced with a quantificational antecedent as in (4) (Chien \& Wexler, 1990).

(4) Every princess is painting her.

In what has been called 'quantificational asymmetry' (Elbourne, 2005), while children have difficulties interpreting sentences such as (1), they have no difficulties understanding examples with quantificational antecedents such as (4) above. The relevance of this finding lies in that local accidental co-reference is impossible with quantificational subjects, as quantifiers are not referential, thus supporting the view

\footnotetext{
${ }^{1}$ Note that there are different views on the type of problems children may have with coreference. An early attempt towards the interpretation of the phenomenon has been the suggestion that children lack a pragmatic principle that regulates local coreference, called Principle P (Chien \& Wexler, 1990). A related account has attributed the phenomenon to children's processing limitations, which prevent them from applying Rule I (Grodzinsky \& Reinhart, 1993). According to the latter view, Rule I places a burden on working memory, as it requires the simultaneous examination of two alternative interpretations. For populations with processing limitations, including typically developing children, this results in failure to apply the rule.
} 
that children have no difficulties with binding (Principle B) and struggle instead with local accidental co-reference.

The link of PIP to local accidental coreference is also supported by findings on children's interpretation of pronominal clitics; relevant studies have shown high percentages of target responses, unlike studies examining stronger types of pronouns. For example, McKee (1992) examined thirty Italian-speaking children on the interpretation of Italian clitics using a TVJ task, and reports $85 \%$ target responses, in sharp contrast with $18 \%$ target responses on the interpretation of strong pronouns by sixty English-speaking children examined in the same study. Similar low percentages of anaphoric interpretations are reported for Spanish (Baauw et al., 1997), French (Hamann, Kowalski \& Philip, 1997), and Greek clitics (Varlokosta, 2000, see section 1.3 below). This effect has been linked to the fact that local coreference, as in (3b) above, is impossible for clitics (5b) (Avrutin \& Wexler, 1992; Conroy et al., 2009). In the Greek examples below, the clitic and noun cannot refer to the same entity (example in (5a) after Varlokosta, 2001b).

(5) Local accidental coreference disallowed

a. O Yanis ton $_{\mathrm{j}}$ ide. the John himCL saw 'John saw him.'

b. Oloi agapane ton Petro. O Yanis ton agapai, i Maria ton agapai, akoma ki o Petros ton agapai. everyone loves the Peter. John himCL loves, the Mary himCL loves, even the Peter himCL loves 
'Everyone loves Peter. John loves him, Mary loves him, even Peter loves him.'

Several related theoretical accounts of this observation have been proposed (e.g. clitics need to establish a dependency with an antecedent through coindexation, as they are referentially dependent, i.e., they cannot refer deictically, Avrutin \& Wexler (1992); or that they need to be bound in order to achieve specification for the feature [human], Baauw et al. (1997)) but most accounts have in common the position that the asymmetry between pronouns and clitics is linked to clitics being subject to binding $^{2}$ and not to coreference (cf. McKee, 1992).

Another factor that can be seen to affect results in experimental studies on pronoun acquisition is experimental task and design. Already in early studies on the subject in the nineties, the importance of experimental design was detected and a number of conditions relevant studies should meet were suggested (Crain \& Thornton, 1998). This was later systematically examined, with relevant controlled studies eliciting different percentages of target responses depending on the task employed (Baauw et al., 2011) or on the methodological manipulations within the same task (Conroy et al., 2009). For example, Baauw et al. (2011) examined 20 Dutch-speaking children aged $4 ; 11$ to $6 ; 0$ on their interpretation of pronouns using two different tasks (Truth Value Judgment (TVJ) task and Picture Selection (PS) task) and found a significant effect of task, such that children performed better when a PS task was used. Conroy et al. (2009) tested three groups of English-speaking children in three separate experiments using different versions of a TVJ task with stories; even though results of the three experiments are not directly comparable, findings indicate that

\footnotetext{
${ }^{2}$ Note that clitics can also be bound in discourse (not only in syntax) (see Baauw et al., 1997).
} 
changes in the story may affect children's performance, as the quantificational asymmetry appeared in only one of the three experiments.

\subsection{Greek pronouns}

Greek is one of the languages that display two types of pronouns, one being strong (strong pronoun, example (6)), and one being deficient (pronominal clitic, example (7)).

(6)

O Gufi skepase afton ${ }^{3}$. the Goofy covered himPRON

'Goofy covered him.'

(7)

O Gufi ton skepase. the Goofy himCL covered 'Goofy covered him.' (examples after Varlokosta, 2000).

The two pronoun types differ in a number of ways (see Mavrogiorgos, 2010; Varlokosta, 2002), which fit the cross-linguistically observed strong-deficient pronoun distinction (Cardinaletti \& Starke, 1999a). For example, morphologically, deficient pronouns are reduced forms of strong pronouns (ton versus afton).

\footnotetext{
${ }^{3}$ Greek examples are not given in strict phonetic or phonemic transcription; they are loosely transcribed to the extent that serves the purposes of the present study.
} 
Moreover, of the two, only strong pronouns can occupy peripheral positions $(8,9)$ (examples after Varlokosta, 2002):

Ine *ton/afton/ton Yani pu thavmazo. $\quad$ (cleft)

is himCL/himPRON/the John that admire- $1 \mathrm{Sg}$

'It is him/John I admire.'

(9) *Tin/aftin/ti Maria, tha tin do.

(left dislocation)

herCL/herPRON/the Mary will herCL see-1Sg

'I will see her/Mary.'

In terms of coreference, Greek clitics follow the cross-linguistic pattern of disallowing coreference of the type discussed in section 1.1 (see 5 above) (Varlokosta 2001b, 2002). Interestingly, Greek strong pronouns, like clitics cross-linguistically, and unlike pronouns in other languages, also disallow local accidental coreference ${ }^{4}$. In

\footnotetext{
${ }^{4}$ This observation has been linked to an important additional property that sets Greek strong pronouns apart from typical strong pronouns (in addition to resistance to local accidental coreference). Greek strong pronouns can refer to non-human entities (Varlokosta, 2000), despite a robust cross-linguistic generalisation (Cardinaletti \& Starke, 1999b) that strong pronouns cannot have non-human referents. The only exceptions to this cross-linguistic generalisation, including Greek afton, have demonstrative morphology (Cardinaletti \& Starke, 1999b). These properties give Greek afton membership to a special pronoun category, which consists of demonstrative pronouns that follow Principle B (Bdemonstratives, Cardinaletti \& Starke, 1999b). According to Cardinalletti \& Starke (1999b), a language may have a demonstrative pronoun following Principle B instead of Principle C, if there is no corresponding personal pronoun in the language in question. These elements are used as strong pronouns (i.e., in contexts requiring strong pronouns), can take non-human referents, and resist local
} 
the example below, the pronoun and noun cannot refer to the same entity (example after Varlokosta, 2001b).

(10) Local accidental coreference disallowed

O Yanis ide $_{\mathrm{i}}$ afton $_{\mathrm{j}}$. the John saw himPRON

'John saw him.'

Moreover, whenever a clitic is possible, a strong pronoun cannot be selected in the same context, as is cross-linguistically the case (Cardinaletti \& Starke, 1999a). For instance, the use of the strong pronoun in (6) above would not be felicitous in the same context as (7), which allows the use of a pronominal clitic. For (6) to be felicitous, a different context would be required (e.g., discourse requiring contrastive use of pronoun). This observation has been formalised in Cardinaletti and Starke's (1999a) pronoun minimality principle: if a language has stronger and weaker types of pronouns, then the most deficient form must be chosen if it can be chosen.

\subsection{The (absence of) PIP in Greek}

Existing studies on the acquisition of Greek pronominal elements indicate that Greek does not participate in the PIP (Varlokosta, 2000, 2001, 2002). Greek-speaking typically developing children do not allow an anaphoric interpretation of pronominal

accidental coreference. (Note that we continue referring to the element afton as strong pronoun throughout the manuscript, to avoid confusion). 
clitics, thus, following the cross-linguistically observed pattern ${ }^{5}$. Moreover, children do not appear to have problems in the interpretation of Greek strong pronouns either (Varlokosta, 2000, 2002). Results similar to those reported in Varlokosta $(2000,2002)$ are reported in other studies of (bilingual) typically developing Greek-speaking children (Sanoudaki, 2004; Varlokosta \& Dullaart, 2001).

The absence of PIP in Greek clitics and strong pronouns has been linked to the ban on local accidental coreference with these elements, presented in section 1.2. (Varlokosta, 2001b, 2002). .

It has also been suggested that the fact that the experimental design in Varlokosta (2000) is one that better satisfies crucial experimental assumptions may have contributed to higher percentages of target responses in this study (Conroy et al., 2009). Varlokosta (2000) used a dynamic TVJ task, where the experimenter uses toys to act out a story before the child is invited to judge the truth value of a target sentence. As demonstrated by Conroy et al. (2009), the storyline is crucial in designing felicitous contexts for truth value judgments: both interpretations (anaphoric and deictic) must be considered at some point in the story, and context must ensure the accessibility of antecedents/referents. Failure to meet these

\footnotetext{
${ }^{5}$ It is worth pointing out that several studies examining atypical Greek-speaking populations, such as children with Specific Language Impairment, have shown that the comprehension and production of these elements tend to pose difficulties to these populations (e.g. Chondrogianni, Marinis \& Edwards, 2010; Stavrakaki \& van der Lely, 2010; Tsimpli \& Stavrakaki, 1999; but see Manika, Varlokosta \& Wexler, 2011; Varlokosta, 2002; Varlokosta, Konstantzou \& Nerantzini, 2014; Varlokosta \& Nerantzini, 2012, for opposite findings). This is in contrast with findings in other languages showing that although the production of these items in children with Specific Language Impairment is problematic, their comprehension is well preserved (e.g., French: Jakubowicz, Nash, Rigaut \& Gérard, 1998).
} 
requirements may be the reason behind PIP-type findings (Conroy et al., 2009). As Varlokosta (2000) is one of the studies that satisfied these assumptions, Conroy and colleagues suggest that children's improved performance in Greek elements may be due to the design of the study in question (although they also note that clitics may be immune to the PIP cross-linguistically).

Experimental findings regarding Greek strong pronouns are unexpected for a further reason: strong pronouns were tested and accepted by children in contexts where they were infelicitous. Recall that strong pronoun cannot be used if a clitic can be used in the same context (section 2.1.). The contexts where the Greek strong pronoun was used in Varlokosta (2000) and other similar studies (Sanoudaki, 2004; Varlokosta \& Dullaart, 2001), were contexts where a pronominal clitic would have been possible (see examples 6 and 7). Note that in Varlokosta (2000) strong pronouns were also tested and accepted by children as appropriate in contexts where a clitic would not be allowed, as in (11) (strong pronoun as complement of a preposition).

(11) O Gufi agorase se afton ena vivlio. the Goofy bought to himPRON a book 'Goofy bought him a book.' (example after Varlokosta, 2000)

However, for examples 5 and 6 , in all the above studies, the context against which test sentences were judged was identical for the strong pronoun condition and the clitic condition. Consequently, results reveal that children accepted as true sentences containing strong pronouns in positions where a clitic should have been selected instead. 
These results are in line with the concept of "pragmatic tolerance" in language acquisition. A range of studies examining informativeness and implicature using versions of the TVJ task (e.g. Guasti, Chierchia, Crain \& Foppolo, 2005; Katsos \& Bishop, 2011) have shown than children are tolerant of pragmatic infelicity, accepting as correct sentences which are not felicitous. For example, children tend to accept underinformative sentences as correct: e.g., 'He picked up some carrots' when the protagonist had picked up all of the carrots (Katsos \& Bishop, 2011).

A question that arises then is whether children in Varlokosta (2000) accepted the infelicitous sentences as true because they do not detect the pragmatic infelicity, or whether they detect the infelicity but, for some reason, choose to treat infelicitous sentences as 'true'. One way to examine this is the use of a different task to examine the interpretation of these infelicitous sentences, such as the PS task. In this task, children are presented with a sentence and asked to make a choice between two pictures, in this case one consistent with a deictic interpretation, and one consistent with an anaphoric interpretation. If children cannot detect the pragmatic violation, then they would consistently choose a picture involving a deictic interpretation for the infelicitous strong pronoun sentences. If, on the other hand, children are able to detect the pragmatic violation, we may find inconsistency in the responses, as children would be forced to make a choice when neither picture would be optimal as a response.

The present study aims at addressing these questions by examining the interpretation of pronominal elements in Greek-speaking children and adults. Two experiments are reported here: first, a picture TVJ task is administered to children and adults. Second, a different group of children and adults are tested using a PS task. 
The version of the TVJ task used in this study will be a picture-based paradigm, unlike Varlokosta's (2000) dynamic story-based TVJ task. This will allow us to better address the question of whether clitics are indeed immune to the PIP, or the results in Varlokosta (2000) are partly due to the storyline better satisfying experimental assumptions, a suggestion made in passing by Conroy et al. (2009). Unlike the dynamic TVJ task, where the context against which sentences will be judged is actively manipulated by the researcher, the picture TVJ task creates minimal context, as the only context provided are the pictures.

The two experiments serve a dual purpose: first, to examine the acquisition of pronouns by Greek-speaking children, and second, to investigate the processing of the pragmatic infelicity in Greek-speaking children and adults when different tasks are employed. By employing two different tasks in the examination of pronouns and clitics in Greek child language, we seek to examine if both Greek clitics and pronouns will elicit high percentages of target responses, as has been the case with familiar tasks, or, alternatively, whether the cross-linguistic asymmetry between clitics and strong pronouns in child language will be detected. Specifically, if Greek strong pronouns indeed pattern with clitics in that they are both resistant to the PIP, then there should be no asymmetry between clitics and strong pronouns in Greek child language irrespective of task - we will be referring to this as the no-asymmetry hypothesis. Alternatively, if children performed well with Greek pronouns in Varlokosta (2000) only because experimental assumptions of the (TVJ) task were met, then the cross-linguistically familiar asymmetry between clitics and strong pronouns in child language (i.e. children experiencing problems with strong pronouns but not clitics) may appear- this will be called the asymmetry hypothesis. Moreover, the infelicity in strong pronoun conditions is explored by examining adult and child 
participants in both tasks (TVJ and PS task). As outlined above, the use of two separate tasks may allow us to establish whether children are able to detect the pragmatic violation or not, and if so, to detect different strategies in the processing of infelicity. The two tasks will be described in detail in the methodology sections. Adult performance will serve as the basis for the interpretation of child performance.

\section{Experiment 1}

\subsection{Participants}

Twenty monolingual Greek children (eight boys, 12 girls; age range 4;02-6;01, mean age 5;03) were tested in two nurseries in Athens. All children were reported by school staff as having normal linguistic and cognitive development and no hearing difficulties or learning disabilities.

Ten Greek-speaking adults (six male, four female; age range 22-65) were also tested in this experiment. Adult participants had been brought up in a monolingual Greek environment in the island of Crete, and had no symptoms or history of language impairment or learning disabilities.

\subsection{Design and materials}

A picture TVJ task (Wexler \& Chien, 1985) was used in this study. In this task, participants are asked to judge whether a statement is true, based on accompanying picture stimuli ${ }^{6}$. Conditions and number of trials in the present experiment were based on Varlokosta (2000), which employed a dynamic TVJ task to test typically

\footnotetext{
${ }^{6}$ This experimental paradigm is also known as picture verification task (Conroy et al., 2009).
} 
1

2

3

4

5

6

7

8

9

10

11

12

13

14

15

16

17

18

19

20

21

22

23

24

25

26

27

28

29

30

31

32

33

34

35

36

37

38

39

40

41

42

43

44

45

46

47

48

49

50

51

52

53

54

55

56

57

58

59

60

developing Greek-speaking children. Visual stimulus consisted of a picture depicting a person performing an action on oneself in the presence of another person (Figure 1) or on the other person (Figure 2). The stimuli were based on materials developed within COST (European Cooperation in Science and Technology) Action A33 'Crosslinguistically Robust Stages of Children's Linguistic Performance' (COST Action A33, 2006-2010).

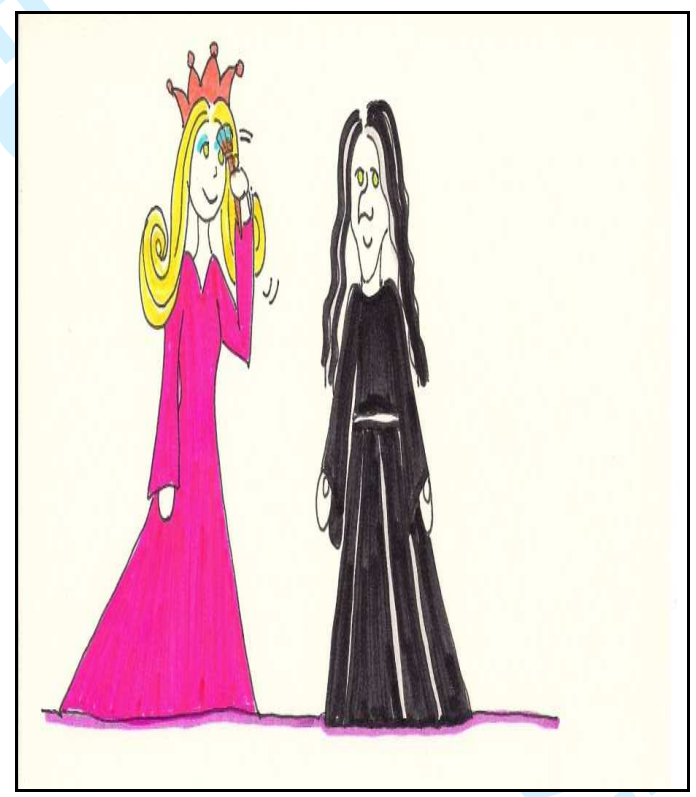

FIGURE 1. Example of the picture stimuli (pictures developed within COST Action A33, 2006-2010) 
FIGURE 2. Example of the picture stimuli (pictures developed within COST Action A33, 2006-2010)

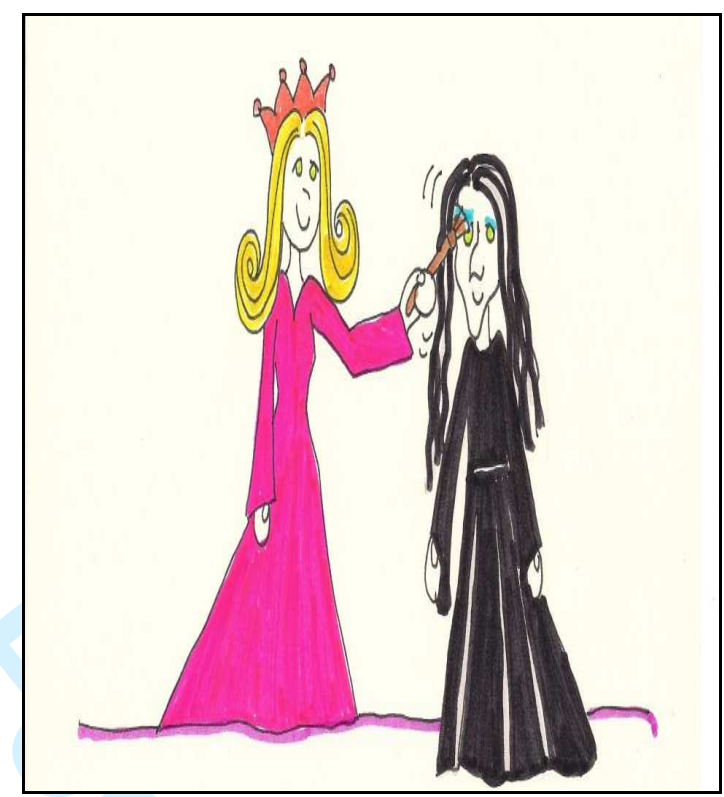

There were two test conditions (i.e. target answer 'no'): one for clitics, and one for strong pronouns. For every test condition there was a corresponding control condition (target answer 'yes'). An additional condition involving reflexive pronouns was included but is not reported here. There were four trials for each test and control condition. Four verbs were used: pleno 'wash', chtenizo 'comb', vafo 'paint', ylifo 'lick'. Each of the four verbs was presented in all experimental conditions. In addition, a filler condition involving nouns only was included (target answer 'no', six trials; target answer 'yes', six trials). Sentences were arranged in two different orders. The first order was randomised, while the second one was the reverse. Presentation order was counterbalanced between participants. Two warm-up items were also included to familiarise participants with the procedure. Examples of the test and control conditions are given in Tables 1 and 2, respectively. The complete list of stimuli can be found in Appendix 1. 
TABLE 1. Test conditions (Target answer "no")

\begin{tabular}{lll}
\hline Condition & No of trials & Example \\
\hline CL & 4 & I prigipisa ti vafi. \\
& the princess herCL is painting \\
& 'The princess is painting her.' \\
\hline PRON & 4 & O skilos $\gamma$ lifi afton. \\
& the dog is licking himPRON \\
& 'The dog is licking it/him.' \\
\hline
\end{tabular}

TABLE 2. Control conditions (Target answer "yes")

\begin{tabular}{lll}
\hline Condition & No of trials & Example \\
\hline CL & 4 & I mama tin pleni. \\
& the mom herCL is washing \\
& 'Mom is washing her.' \\
& & O nanos chtenizi afton. \\
PRON & the dwarf is combing himPRON \\
& 'The dwarf is combing him.' \\
\hline
\end{tabular}

Each test sentence was preceded by an introductory sentence, presenting the two characters. The first character in the introductory sentence was the one performing the action shown in the picture stimuli and described in the test sentence. For example:

(12a) Introductory sentence

Edo vlepume mia kamilopardali ke mia ajelada. here we see a giraffe and a cow 
'Here we see a giraffe and a cow.'

(12b) Test sentence

I kamilopardali ti $\quad \gamma$ lifi.

the giraffe herCL is licking

'The giraffe is licking it/her.'

\subsection{Procedure}

The experimenter first spent some time with the children in their classroom or in the schoolyard, so as to become familiar to them. Then each child was tested individually in a quiet room. Children were then presented with the experimental task. The linguistic and the picture stimuli were presented simultaneously.

During practice, participants were encouraged to look at the picture while listening to the sentence and answer 'yes or no'. Following practice, instructions were not repeated unless the child did not point to either picture. In such cases, the same trial, including instructions, was repeated. The picture stimuli were presented on a 15.6" computer screen, and the sentences were read aloud with neutral prosody by the experimenter. The task was completed in one session, with short breaks of spontaneous discussion and playing in between, as and when needed. Child participants were tested in a quiet room in their school and adults in their home.

\subsection{Results}


1

2

3

4

5

6

7

8

9

10

11

12

13

14

15

16

17

18

19

20

21

22

23

24

25

26

27

28

29

30

31

32

33

34

35

36

37

38

39

40

41

42

43

44

45

46

47

48

49

50

51

52

53

54

55

56

57

58

59

60

Percentages of target responses for the child group are given in Figure 3, and for adults in Figure 4. As can be seen, performance was generally high in all conditions. In the child group, percentages of target responses on the clitic conditions were $100 \%$ (control) and 90\% (test), and on the pronoun conditions 91\% (control) and 79\% (test). In the adult group, percentages of target responses on the clitic conditions were $96 \%$ (control) and $100 \%$ (test), and on the pronoun conditions $95 \%$ (control) and $92 \%$ (test) $)^{7}$.

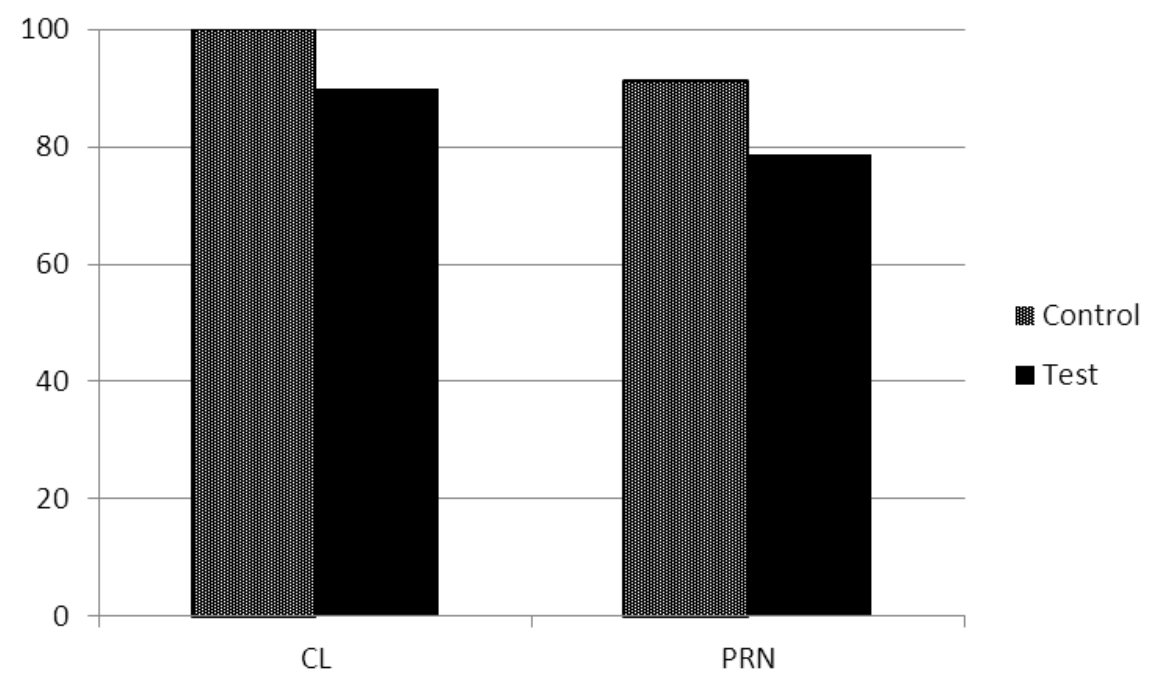

FIGURE 3. Percentage of target responses on each of the control and test conditions: clitic (CL) and strong pronoun (PRON). Child group.

\footnotetext{
7 On the reflexive conditions, adults gave target responses $100 \%$ of the time (control and test conditions), while the corresponding percentages for the child group were $96 \%$ and $99 \%$, respectively.
} 


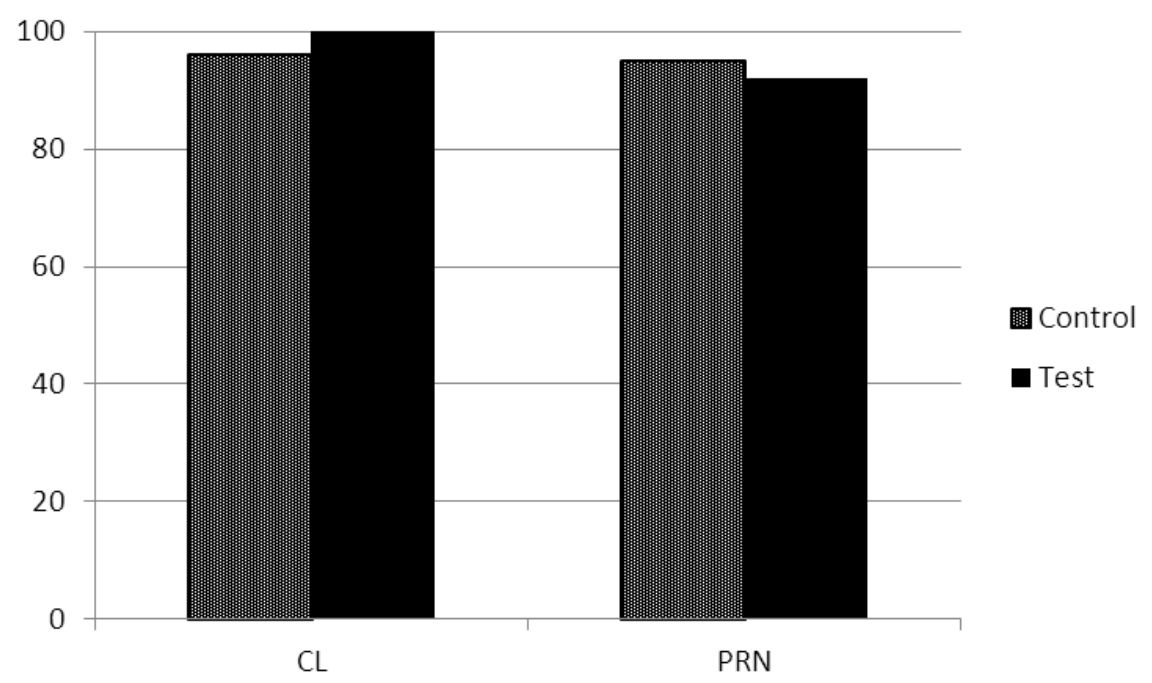

FIGURE 4. Percentage of target responses on each of the control and test conditions: clitic (CL) and strong pronoun (PRON). Adult group.

Statistical analysis of the child data showed no significant difference between test and control conditions for clitics $(z=2.271, p=.023, r=0.359)$ and for strong pronouns $(z=1.533, p=.125, r=0.242)$, and no difference between clitics and pronouns for control conditions $(z=2.121, p=.034, r=0.335)$ and for test conditions $(\mathrm{z}=1.634$, $p=.102, r=0.258$ ) (Wilcoxon signed rank tests, significance level set at $p<.012$ to control for Type I error).

Similarly, for the adult data, all comparisons remained below significance (clitics control versus clitics test: $z=1.0, p=.317, r=-0.224$; pronouns control versus pronouns test: $z=.447, p=.655, r=0.1$; clitics control versus pronouns control: $z=0.577$, $p=.564, \quad r=0.129 ;$ clitics test versus pronouns test: $z=1.732, p=.083, r=0.387$ ) (Wilcoxon signed rank tests, significance level set at $p<.012$ ).

A between group analysis showed no statistically significant difference between the child and the adult group in any condition (clitics control $p=.681$, clitics test $p=.198$, pronoun control $p=.812$, pronouns test $p=.422$, Mann-Whitney $\mathrm{U}$ test). 
Overall, no differences were detected in any of the between- and within-group comparisons.

\subsection{Interim discussion}

This experiment examined the interpretation of pronominal clitics and strong pronouns in monolingual Greek-speaking children and adults using a picture TVJ task. Children accepted a deictic interpretation and rejected an anaphoric interpretation of clitics and strong pronouns, thus, replicating findings of studies using a dynamic TVJ task with Greek-speaking children (Varlokosta, 2000).

The present experiment, by including adults, provided a model against which children's responses could be evaluated, especially with regard to the interpretation of strong pronouns. Similarly to children, adults accepted a deictic interpretation (and rejected an anaphoric interpretation) of strong pronouns. Before attempting to analyse these results and their implications for the existence of infelicity in experimental sentences, we report on a second experiment, which examines the interpretation of pronouns in both children and adults using a task that has not been previously employed to assess strong pronouns in Greek-speaking populations.

\section{Experiment 2}

\subsection{Participants}

Nineteen monolingual Greek children (nine boys, ten girls; age range 4;05-6;03, mean age $5 ; 04)$ were tested in this experiment. Four more children were excluded because 
they did not understand the experimental task or they did not manage to complete the tests. The children were tested in three nurseries in Iraklio, in the Greek island of Crete. All children were reported by school staff as having normal linguistic and cognitive development, and no hearing difficulties or learning disabilities. A cut-off point of seven correct responses out of nine in the control condition (see section 3.2 below) had been pre-determined as an additional measure for the selection of child participants. All children who managed to complete the tests satisfied this criterion.

Eighteen adults (thirteen women, five men; age range 23-67), who had not participated in Experiment 1, were also tested in this experiment. All adult participants were raised in a monolingual Greek environment in Crete and had no symptoms or history of language impairment, or learning disabilities.

\subsection{Design and materials}

A manual Picture Selection task was used in this study. The PS task has been used to examine children's interpretation of a wide range of (morphosyntactic) contrasts, such as the distinction between affirmative and negative (Fraser, Bellugi \& Brown, 1963), the use of determiners (Katz, Baker \& McNamara, 1974), etc. The PS task has also been used in research on binding by Wexler and Chien (1985), Deutsch, Koster \& Koster (1986), Baauw et al. (2011), Varlokosta \& Nerantzini (2012).

Participants listened to sentences and were asked to choose one of two pictures for each sentence by pointing to it with their finger. Within each picture pair, one picture depicted a person performing an action on somebody else, while the other picture presented the same person performing the same action on themselves in the 


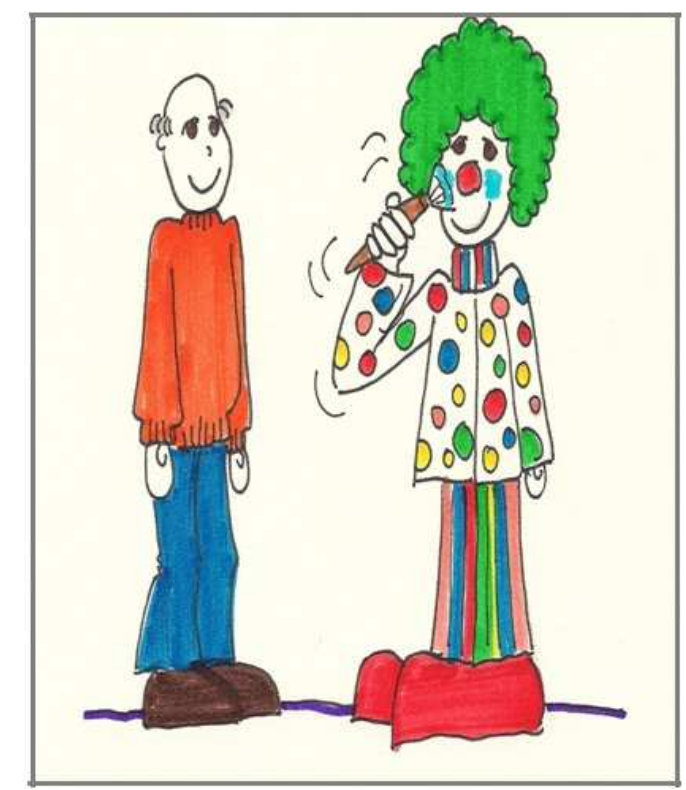

presence of the other person (see Figure 5). As in the previous experiment, the stimuli were based on materials developed within COST Action A33 (2006-2010).

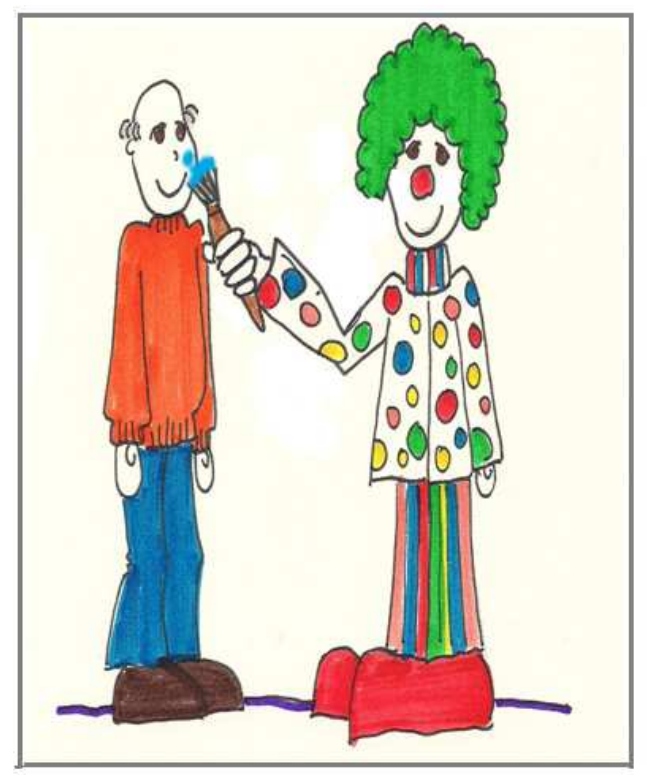

FIGURE 5. Example of the picture stimuli (pictures developed within COST Action A33, 2006-2010)

There were two test conditions: clitic (CL), and strong pronoun (PRON), and one control condition, involving nouns only (CNTRL). Two further conditions involving reflexive pronouns were also included but are not reported here. There were nine trials for each condition. An example for each condition is given in Table 3.

TABLE 3. Experimental conditions

\begin{tabular}{lll}
\hline Condition & No of trials & Example \\
\hline CL & 9 & O prigipas ton skepazi. \\
& the prince himCL is covering \\
& 'The prince is covering him.'
\end{tabular}




\begin{tabular}{ll}
\hline PRON & 9 \\
& I mama skupizi aftin. \\
the mum is drying herPRON \\
'Mum is drying her.' \\
\hline CNTRL 99 & I magisa chtenizi ti vasilisa. \\
the witch is combing the queen \\
'The witch is combing the queen.'
\end{tabular}

Nine verbs were used: pleno 'wash', chtenizo 'comb', vafo 'paint', ylifo 'lick', skupizo 'dry', skepazo 'cover', agaliazo 'hug', agizo 'touch', zoyrafizo 'draw'. Each of the nine verbs was presented in all test conditions as well as in the control condition. One further verb, vrecho 'soak', was used to create two practice items. Five picture fillers were included. The pictures were drawings of novel animals, and they were included to renew the participants' interest in the task.

As in experiment 1 , sentences were arranged in two different orders. The first randomised order can be seen in Appendix 2. Each test sentence was preceded by an introductory sentence, presenting the two characters, as described for experiment 1 (section 2.3). For example:

(13a) Introductory sentence

Edo vlepume ena prigipa ki ena nano.

here we see a prince and a dwarf

'Here we see a prince and a dwarf.'

(13b) Test sentence

O prigipas ton skepazi.

the prince himCL is covering 
'The prince is covering him.'

\subsection{Procedure}

The picture pairs were shown side by side on a 15.6" computer screen, and the linguistic stimuli were presented by the experimenter with neutral prosody.

During practice, the experimenter asked the participant to 'show [her] which picture matches this' (i.e. the sentence). As in experiment 1, instructions were not given in trials following practice, except for cases when the child did not point to either picture. All remaining aspects of the procedure were identical to those described in section 2.3 for experiment 1 .

\subsection{Results}

Figure 6 shows the percentage of target responses for the child and adult groups for each condition.

Responses of the child group on the control and clitic conditions were at ceiling (98\% and $95 \%$, respectively), while the strong pronoun condition presented a lower percentage $(74 \%)^{8}$. Statistical testing revealed a significant difference between different conditions in children's performance $p<.001$ (Friedman test). Post-hoc analysis with Wilcoxon Signed-Rank Tests was conducted with a Bonferroni correction applied, resulting in a significance level set at $p<.017$. Tests showed a

\footnotetext{
${ }^{8}$ Responses on the reflexive condition were at ceiling (95\% target). In the adult group, the percentage for reflexives was $100 \%$.
} 
statistically significant difference between children's performance at the control condition and their performance at the strong pronoun condition $(p<.001)$, as well as between the clitic and strong pronoun conditions $(p=.002)$. A comparison between the control condition and the clitic condition was below significance $(p=.206)$.

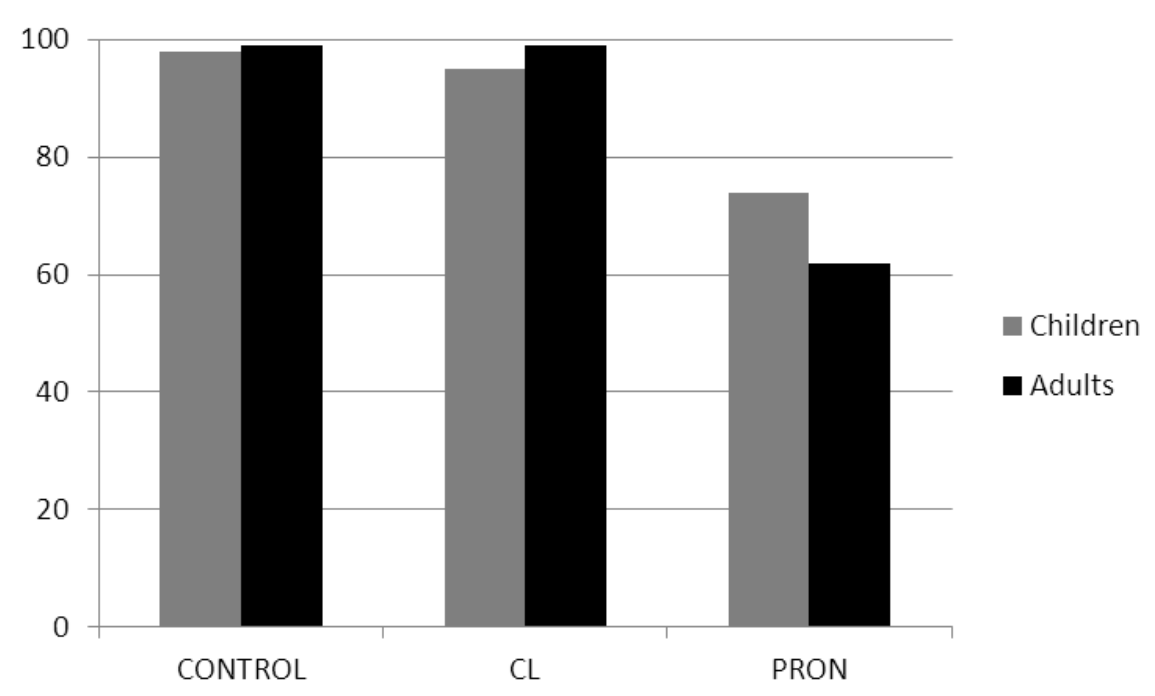

FIGURE 6. Percentage of target responses for the child and adult group on each condition; control (CONTROL), clitic (CL), and strong pronoun (PRON).

For the adult group, results reveal almost $100 \%$ target responses in all conditions apart from the strong pronoun condition, which had $62 \%$ target responses. There was a statistically significant difference between different conditions in adults' performance $p<.001$ (Friedman test). As before, post-hoc analysis with Wilcoxon Signed-Rank Tests was conducted with a Bonferroni correction applied, resulting in a significance level set at $p<.017$. The strong pronoun condition differed significantly from both remaining conditions (control versus strong pronoun $p=.001$, clitic versus strong pronoun $p=.001$ ), while the comparison between the control condition and clitic condition was not significant $(p=1)$. 
Finally, in a comparison between children's and adults' performance, using Mann-Whitney U test, no statistically significant difference was detected in any of the conditions tested.

Overall, testing confirmed that children's performance was lower at the strong pronoun condition, while it did not differ from adult performance, which was also low at the strong pronoun condition.

\section{Discussion}

Our findings show that Greek pronouns are not subject to PIP. Greek-speaking children respond in an adult-like fashion in tests examining their interpretation of both strong pronouns and pronominal clitics. Moreover, experimental manipulations did not seem to influence children's adult-like behaviour, as children consistently gave adult-like responses irrespective of the experimental task employed.

However, our experimental results indicated that children as well as adults often assign an anaphoric reading to the strong pronoun when a PS task is employed (Experiment 2). This was not the case in the picture TVJ task (Experiment 1), when either children or adults are tested, as both populations accepted only a deictic interpretation for the strong pronoun.

Note that the detected difference between Greek clitics and pronouns cannot be linked to the clitic-pronoun asymmetry hypothesis in language acquisition. According to the asymmetry hypothesis, children have difficulties in establishing the adult interpretation for strong pronouns (but not clitics), occasionally interpreting them as reflexive elements. In contrast, our results indicate that children have adult- 
like interpretations for both elements, following adults in occasionally assigning anaphoric interpretations to strong pronouns when tested with a PS task. Consequently, the results of experiment 2 (PS task) cannot be straightforwardly employed to support either hypothesis on the relationship between clitics and pronouns in child language (asymmetry or no-asymmetry).

The asymmetry between clitics and strong pronouns detected in both child and adult groups is linked instead to the infelicity of strong pronoun sentences, and reveals different effects of infelicity on performance depending on the task. Recall (section 1.3) that experimental sentences containing Greek strong pronouns employed in the acquisition literature are infelicitous. A pronominal clitic could, and, thus, should be used in the relevant context, instead of the strong pronoun. The sentences in question contain a minimality principle violation (Cardinaletti \& Starke, 1999b). Our experimental results indicate that this violation influences performance in both children and adults when a PS task is used, but not when a picture TVJ task is used.

The failure to detect any effect of the minimality violation in the results of the picture TVJ task is in line with findings from the field of experimental pragmatics showing tolerance to pragmatic infelicity when a TVJ task is used (Katsos \& Bishop, 2011, see section 1.3 above $)^{9}$. It appears that participants in the TVJ task simply assign a Principle B abiding (i.e. deictic) interpretation to strong pronoun sentences and evaluate this against the events (or picture), accepting the sentence as true (or rejecting this as false) depending on the picture, irrespective of any minimality violations.

In contrast, in the PS task, responses appear to violate Principle B around one third of the time. We argue that this violation of the syntactic principle is only

\footnotetext{
${ }^{9} \mathrm{We}$ are grateful to the anonymous reviewers for their helpful suggestions regarding task differences.
} 
apparent, indicating instead a strategy applied to resolve a conflict between different grammatical requirements. In this task, the two pictures presented forced participants to consider two alternative interpretations for the sentence, one anaphoric and one deictic. We suggest that participants, facing a choice between two interpretations, one violating Principle B (anaphoric interpretation) and the other violating pronoun minimality (deictic interpretation), followed one of the following two strategies. The majority of child and adult participants ( $74 \%$ and $62 \%$, respectively) selected the picture consistent with the deictic interpretation, choosing to ignore or amend the violation of minimality by replacing the strong pronoun with a clitic. Several of our adult participants who chose this strategy repeated the test sentence aloud substituting the clitic for the pronoun, while some performed clitic doubling (14), which would also be allowed in this context.

O kloun ton vafi ton papu. the clown himCL is painting the grandpa 'The clown is painting grandpa.'

Some of the participants chose instead to amend the sentence in a way that allows an anaphoric interpretation, by adding (often aloud, while pointing to the relevant picture) the element 'ton idhio', which allows the sentence to take an anaphoric interpretation.

O kloun vafi afton ton idhio. the clown is painting himPRON the same 'The clown is painting him himself.' 
The claim that participants followed two distinct strategies for the resolution of the conflict in the strong pronoun condition is also supported by the distribution of their responses in the relevant condition. The histogram of deictic responses for the adult group (Figure 7), showing how many adults gave 1, 2, 3, etc. non-anaphoric responses, reveals a pattern that resembles a bimodal distribution, rather than a binomial distribution. If participants were answering uniformly and randomly, we would expect to see a binomial distribution with one mode at four or five. What we see instead is a concentration of responses at the two edges (with a preference for the right edge) and a dip at the centre, indicating the presence of two distinct groups, one of which prefers the anaphoric interpretation, while the other prefers the deictic one.

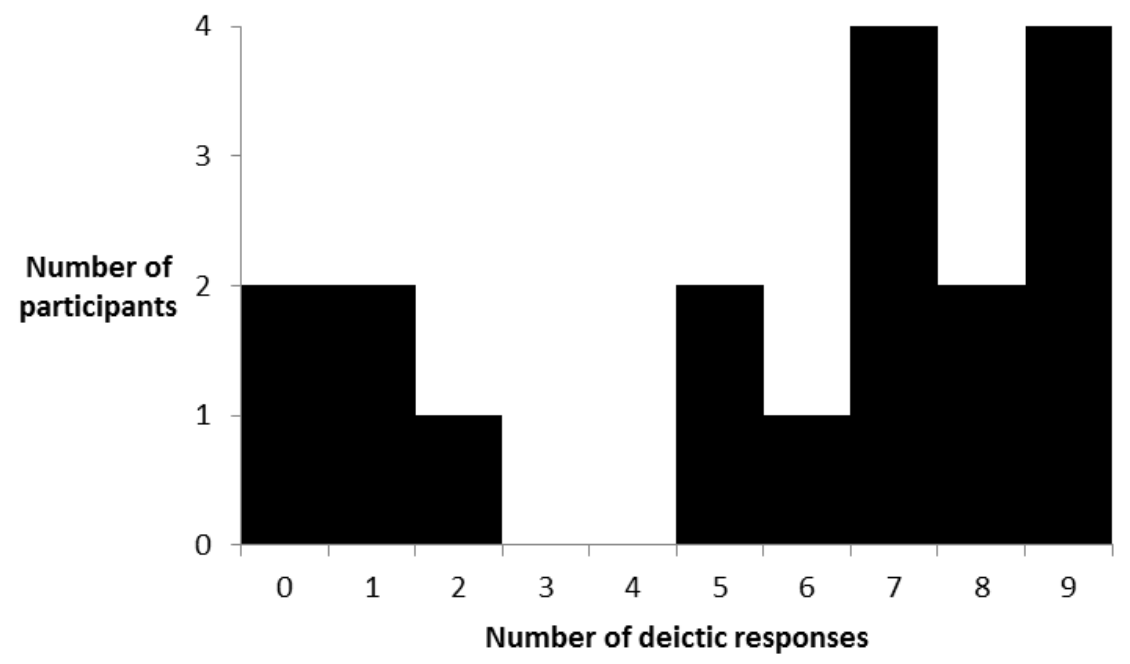

FIGURE 7. Histogram of deictic responses in the strong pronoun condition, PS task, adults.

A similar albeit weaker trend can be observed in the corresponding histogram of the child group (Figure 8). 
FIGURE 8. Histogram of deictic responses in the strong pronoun condition, PS task, children.

The patterns observed in these histograms are consistent with the existence of two distinct strategies in the participants' responses.

Note that the suggested analysis involves an extra-linguistic strategy applied in order to conform to task demands. It is not suggested here that participants sometimes construct a linguistic representation of the sentence which involves an anaphoric interpretation of the strong pronoun in the experimental sentence, as this is not possible in Greek. Instead, the strategy reflects task pressures to settle in one of two choices when neither is suitable. ${ }^{10}$ As this is the first study to reveal such effects, further theoretical and empirical research, including the use of different tasks to test the interpretation of felicitous and infelicitous pronoun sentences, will shed more light on the mechanisms involved.

Our results suggest that children have knowledge of binding and pragmatic conditions of pronoun interpretation. In the pronoun literature, our findings are in line

\footnotetext{
${ }^{10}$ We thank an anonymous reviewer for his input regarding the nature of the mechanisms in question.
} 
with the increasing awareness that children interpret personal pronouns in an adultlike fashion from very early on: results of a recent study combining a PS task and online methods (eye-tracking) indicate that children start to identify the correct referent of Dutch pronouns at the age of four (Bergmann et al., 2012).

It is worth noting here an apparent paradox arising in the juxtaposition of the present study with the pronoun literature, notably the Conroy et al. (2009) results: on the one hand, it is argued here that pragmatic tolerance leads children to accept (otherwise true) infelicitous strong pronoun sentences in TVJ tasks. On the other hand, Conroy et al.'s (2009) analysis holds that the PIP is primarily due to children rejecting (otherwise true) infelicitous sentences (in TVJ tasks). However, we argue that this inconsistency is only superficial: in the latter case the term infelicity is mostly linked to insufficient accessibility of relevant antecedents, possibly creating a processing difficulty. In the present case, as in similar studies of informativeness and implicature, no accessibility/processing issue arises (although processing considerations may also be relevant in certain cases in informativeness tasks (Pouscoulous, Noveck, Politzer \& Bastide, 2007)): infelicity relates to the violation of pragmatic conditions (minimality, in this case), which children (as well as adults) seem to tolerate. The combined results of the two tasks in the resent study show that children have sophisticated knowledge of pragmatic conditions. This is in line with recent evidence in the experimental pragmatics literature, showing that children's response to infelicity in tasks testing informativeness and implicature is not due to lack of pragmatic competence (Katsos \& Bishop, 2011). Evidence for pragmatic tolerance has been found in several studies, examining various aspects of pragmatic infelicity. For example, Robinson \& Whittaker (1985) report that children are able to detect ambiguity even though they respond as if they had not detected it. In some 
cases, children are found to be more tolerant than adults (Guasti et al., 2005), although in the present case children responded in an adult-like fashion.

The present study focused on Greek, but the methodological issues that were raised can be implemented in the study of other languages: for example, future research could seek to replicate findings in relation to minimality violations in other languages that have more than one personal pronoun type. Crucially, future (and existing) studies of the PIP can now be evaluated under a new light. Current findings, and experience from the sophisticated experimental pragmatics literature tell us that designs that do not meet all felicity conditions need not be dismissed as flawed: such tasks are useful in providing information about children's understanding of and access to pragmatic conditions. Manipulations of context and combinations of different tasks can help shed light on how children (and adults) (mis)interpret pronouns and why, even when they have the necessary syntactic and pragmatic competence.

\section{Conclusion}

The present study examined the comprehension of pronouns in Greek-speaking children and adults. In line with cross-linguistic findings, results show that pronominal clitics do not present problems to typically developing children, irrespective of task choice. At the same time, our findings highlight the significance of task selection by revealing that responses in children and adults showed sensitivity to certain properties of the elements tested when one task (PS task) was employed, but less so when a different task (picture TVJ task) was used. These effects were linked to the interplay of experimental task with infelicity in pronoun type selected, in the first study to examine strategies in dealing with this type of infelicity. 


\section{References}

Avrutin, Sergey \& Kenneth Wexler. 1992. Development of principle B in Russian: Coindexation at LF and coreference. Language Acquisition 2. 259-306.

Baauw, Sergio. 1999. The role of clitic-full pronoun distinction in the acquisition of pronominal reference. Proceedings of the $23^{\text {rd }}$ Boston University Conference on Language Development [BUCDL 23], 32-43. Somerville, MA: Cascadilla Press.

Baauw, Sergio, Maria Escobar \& William Philip. 1997. A delay of principle B effect in Spanish speaking children: The role of lexical feature acquisition. In Antonella Sorace, Caroline Heycock \& Richard Shillcock, (eds.), Proceedings of the GALA 97 Conference on Language Acquisition (Generative Approaches to Language Acquisition), 16-21. University of Edinburgh.

Baauw, Sergio, Shalom Zuckerman, Esther Ruigendijk \& Sergey Avrutin. 2011. Principle B delays as a processing problem: Evidence from task effects. In Angela Grimm, Anja Muller, Cornelia Hamann \& Esther Ruigendijk (eds.), Production-Comprehension Asymmetries in Child Language, 247-272. Berlin: Mouton De Gruyter.

Bergmann, Christina, Markus Paulus \& Paula Fikkert. 2012. Preschoolers' comprehension of pronouns and reflexives: The impact of the task. Journal of Child Language 39. 777-803.

Cardinaletti, Anna \& Michal Starke. 1999a. The typology of structural deficiency: A case study of the three classes of pronouns. In Henk van Riemsdijk (ed.), Clitics in the Languages of Europe, 145-233. Berlin-New York: Mouton de Gruyter. 
Cardinaletti, Anna \& Michal Starke. 1999b. Responses and demonstratives. In Henk van Riemsdijk (ed.), Clitics in the Llanguages of Europe, 273-290. BerlinNew York: Mouton de Gruyter.

Chien, Yu-Chin \& Kenneth Wexler. 1990. Children's knowledge of locality conditions in binding as evidence for the modularity of syntax and pragmatics. Language Acquisition 1. 225-295.

Chomsky, Noam. 1981. Lectures on Government and Binding. Dordrecht: Foris.

Chomsky, Noam. 1986. Knowledge of Language: Its Nature, Origin and Use. New York: Praeger.

Chondrogianni, Vicky, Theo Marinis \& Susan Edwards. 2010. On-line processing of articles and pronouns by Greek successive bilingual children: Similar or different from children with SLI? Proceedings of $34^{\text {th }}$ Boston University Conference on Language Development [BUCLD 34], 78-89. Somerville, MA: Cascadilla Press.

Conroy, Anastasia, Eri Takahashi, Jeff Lidz \& Colin Phillips. 2009. Equal treatment for all antecedents: How children succeed with principle B. Linguistic Inquiry 40. 446-486.

COST Action A33 (2006-2010). Cross-Linguistically Robust Stages of Children's Linguistic Performance with Applications to the Diagnosis of Specific Language Impairment. Brussels: COST Office, http://www.zas.gwzberlin.de/cost.html?andL=0.

Crain, Stephen \& Rosalind Thornton. 1998. Investigations in Universal Grammar: A Guide to Experiments on the Acquisition of Syntax and Semantics. Cambridge, MA: MIT Press. 
Deutsch, Werner, Charlotte Koster \& Jan Koster. 1986. What can we learn from children's errors in understanding anaphora? Linguistics 24. 203-225.

Elbourne, Paul. 2005. On the acquisition of principle B. Linguistic Inquiry 36. 333365.

Elbourne, Paul. 2008. The interpretation of pronouns. Language and Linguistics Compass 2. 119-150.

Fraser, Colin, Ursula Bellugi \& Roger Brown. 1963. Control of grammar in imitation, comprehension, and production. Journal of Verbal Learning and Verbal Behavior 2. 121-35.

Grodzinsky, Yosef \& Tanya Reinhart. 1993. The innateness of binding and coreference. Linguistic Inquiry 24. 69-102.

Guasti Maria Teresa, Gennaro Chierchia, Stephen Crain, Francesca Foppolo, Andrea Gualmini \& Luisa Meroni. 2005. Why children and adults sometimes (but not always) compute implicatures. Language and Cognitive Processes 20. 667696.

Hamann, Cornelia, Odette Kowalski \& William Philip. 1997. The French 'Delay of Principle B Effect'. Proceedings of the $21^{\text {st }}$ Boston University Conference on Language Development [BUCLD 21], 205-219, Somerville, MA: Cascadilla Press.

Hartman, Jeremy, Yasutada Sudo \& Ken Wexler. 2012. Principle B and phonologically reduced pronouns in child English. Paper presented at the $5^{\text {th }}$ Generative Approaches to Language Acquisition, North America [GALANA 5], October 11-13, University of Kansas. 
Jakubowicz, Ceila. 1984. On markedness and binding principles. In Ch. Jones and P. Sells (ed.), Proceedings of North East Linguistic Society [NELS] 14, 154-182. Amherst: University of Massachusetts.

Jakubowicz, Celia, Lea Nash, Catherine Rigaut \& Gerard Christophe-Loic. 1998. Determiners and clitic pronouns in French-speaking children with SLI. Language Acquisition 7. 113-160.

Katsos, Napoleon \& Dorothy Bishop. 2011. Pragmatic tolerance: Implications for the acquisition of informativeness and implicature. Cognition 120. 67-81.

Katz, Nancy, Erica Baker \& John Macnamara. 1974. What's in a name? A study of how children learn common and proper names. Child Development 45. 469473.

Manika, Sophia, Spyridoula Varlokosta \& Kenneth Wexler. 2011. The lack of omission of clitics in Greek children with SLI: An experimental study. Proceedings of the $35^{\text {th }}$ Boston University Conference on Language Development [BUCLD 35], 429-437. Somerville, MA: Cascadilla Press.

Mavrogiorgos, Marios. 2010. Clitics in Greek. A Minimalist Account of Proclisis and Enclisis. Amsterdam: Benjamins.

McDaniel, Dana, Helen Smith Cairns \& Jennifer Ryan Hsu. 1990. Binding principles in the grammar of young children. Language Acquisition 1. 121-139.

McKee, Cecile. 1992. A comparison of pronouns and anaphors in Italian and English acquisition. Language Acquisition 2. 21-54.

Philip, William \& Peter Coopmans. 1996. The double Dutch delay of principle B effect. Proceedings of the $20^{\text {th }}$ Boston University Conference on Language Development [BUCLD 20], 629-642. Somerville MA: Cascadilla Press. 
Pouscoulous, Nausicaa, Ira Noveck, Guy Politzer \& Anne Bastide. 2007. A developmental investigation of processing costs in implicature production. Language Acquisition 14. 347-376

Robinson, Elizabeth \& Steve Whittaker. 1985. Children's responses to ambiguous messages and their understanding of ambiguity. Developmental Psychology 21. 446-454.

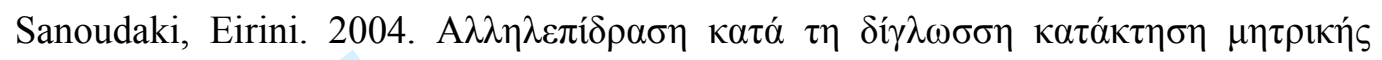

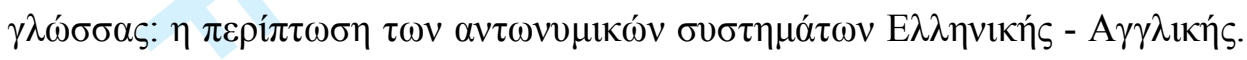
[Bilingual first language acquisition: On the acquisition of pronominal reference by Greek - English bilingual children.] Proceedings of the $6^{\text {th }}$ International Conference of Greek Linguistics [ICGL]. University of Crete, ISBN: 960-88268-0-2.

Sigurjónsdóttir, Sigga \& Nina Hyams. 1992. Reflexivization and logophoricity: Evidence from the acquisition of Icelandic. Language Acquisition 2. 359-413.

Solan, Lawrence. 1987. Parameter setting and the development of pronouns and reflexives. In Thomas Roeper \& Edwin Williams (eds.), Parameter Setting, 189-210. Dordrecht: Reidel.

Stavrakaki, Stavroula \& Heather van der Lely. 2010. Production and comprehension of pronouns by Greek children with specific language impairment. British Journal of Developmental Psychology 28. 189-216.

Thornton, Rosalind. 1990. Adventures in Long-Distance Moving: The Acquisition of Complex Wh-Questions. University of Connecticut Doctoral Dissertation.

Tsimpli, Ianthi Maria \& Stavroula Stavrakaki. 1999. The effects of a morphosyntactic deficit in the determiner system: The case of a Greek SLI child. Lingua 108. $31-85$. 
Varlokosta, Spyridoula. 2000. Lack of clitic pronoun distinctions in the acquisition of principle B in child Greek. Proceedings of the $24^{\text {th }}$ Boston University Conference on Language Development [BUCLD 24], 738-748. Somerville, MA: Cascadilla Press.

Varlokosta, Spyridoula. 2001a. On the acquisition of pronominal and reflexive reference in child Greek. In Margareta Almgren, Andoni Barreña, María-José Ezeizabarrena, Itziar Idiazabal \& Brian MacWhinney (eds.), Research on Child Language Acquisition, 1383-1400. Somerville, MA: Cascadilla Press.

Varlokosta, Spyridoula. 2001b. Typology of pronouns and the DPBE in child Greek. UCL invited talk/unpublished ms., University of Reading.

Varlokosta, Spyridoula. 2002. (A)symmetries in the acquisition of principle B in typically-developing and specifically language impaired (SLI) children. In Ingeborg Lasser (ed.), The Process of Language Acquisition, 81-98. Berlin: Peter Lang Verlag Publishing.

Varlokosta, Spyridoula \& Joanna Dullaart. 2001. The acquisition of pronominal reference by Greek-Dutch bilingual children: Evidence for early grammar differentiation and autonomous development in bilingual first language acquisition. Proceedings of the $25^{\text {th }}$ Boston University Conference on Language Development [BUCLD 25], 780-791. Somerville, MA: Cascadilla Press.

Varlokosta, Spyridoula \& Michaela Nerantzini. 2012. Pronominal and anaphoric reference in Greek specific language impairment. In Zoi Gavriilidou, Ageliki Efthymiou, Evangelia Thomadaki \& Penelope Kambakis-Vougiouklis (eds), Selected Papers of the $10^{\text {th }}$ International Conference on Greek Linguistics, 584591. Komotini: Democritus University of Thrace. http://www.icgl.gr/en.html 
Varlokosta, Spyridoula, Katerina Konstanzou \& Michaela Nerantzini. 2014. On the production of direct object clitics in Greek typical development and specific language impairment: The effect of task selection. In Kleanthes K. Grohmann \& Theoni Neokleous (eds), Developments in the Acquisition of Clitics, 188211. Newcastle upon Tyne: Cambridge Scholars Publishing.

Wexler, Kenneth, \& Yu-Chin Chien. 1985. The development of lexical anaphors and pronouns. Papers and Reports on Child Language Development 24. 138-149. Stanford University. 


\section{Appendix 1}

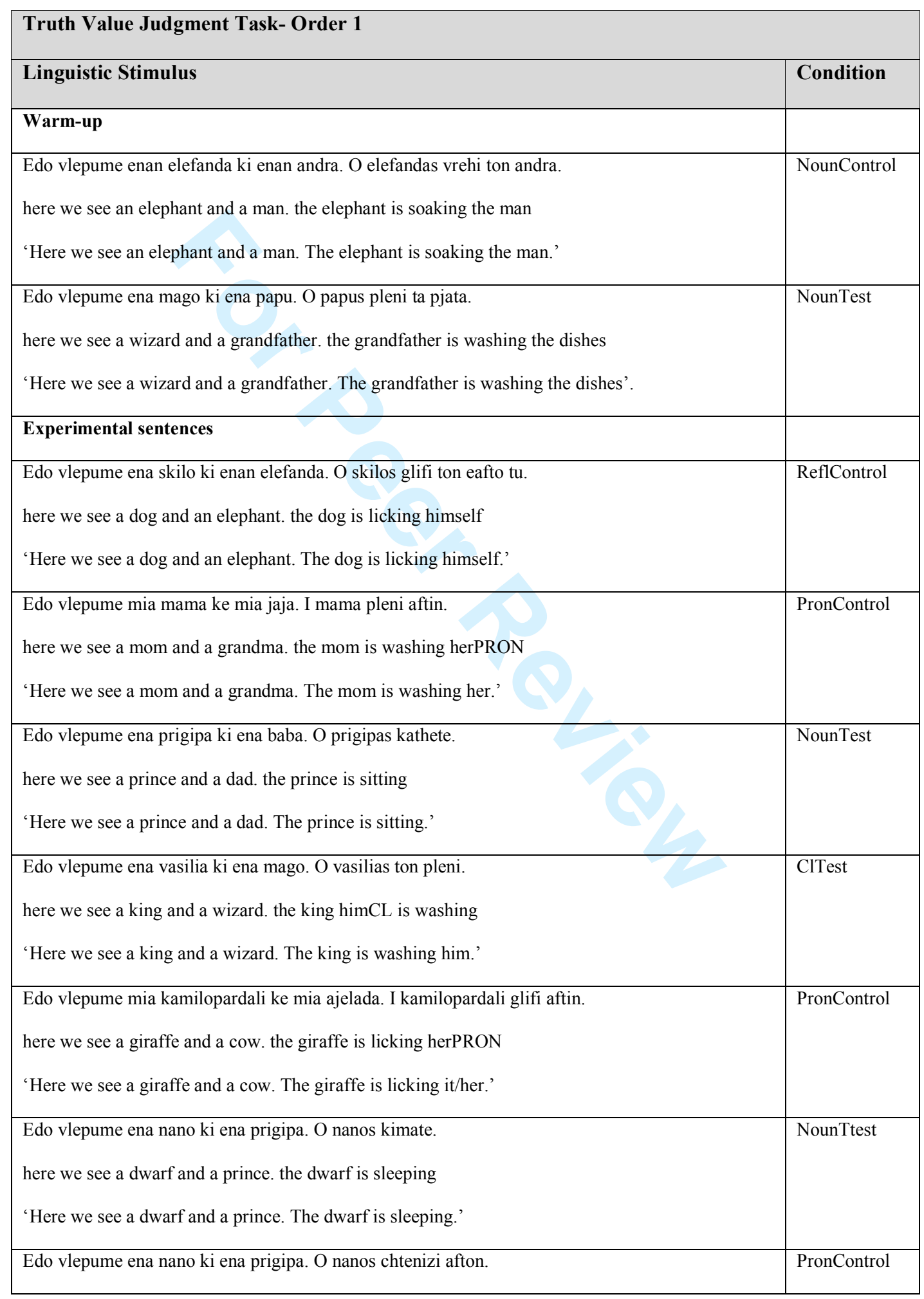




\begin{tabular}{|c|c|}
\hline $\begin{array}{l}\text { here we see a dwarf and a prince. the dwarf is combing himPRON } \\
\text { 'Here we see a dwarf and a prince. The dwarf is combing him.' }\end{array}$ & \\
\hline $\begin{array}{l}\text { Edo vlepume ena skilo ki enan elefanda. O skilos ton glifi. } \\
\text { here we see a dog and an elephant. the dog himCL is licking } \\
\text { 'Here we see a dog and an elephant. The dog is licking him.' }\end{array}$ & ClControl \\
\hline $\begin{array}{l}\text { Edo vlepume mia prigipisa ke mia magisa. I prigipisa vafi ton eafto tis. } \\
\text { here we see a princess and a witch. the princess is painting herself } \\
\text { 'Here we see a princess and a witch. The princess is painting herself.' }\end{array}$ & ReflTest \\
\hline $\begin{array}{l}\text { Edo vlepume ena baba ki enan papu. O papus forai ble panteloni. } \\
\text { here we see a dad and a granddad. the grandad is wearing blue trousers } \\
\text { 'Here we see a dad and a granddad. The granddad is wearing blue trousers.' }\end{array}$ & NounControl \\
\hline $\begin{array}{l}\text { Edo vlepume mia magisa ke mia horeftria. I magisa chtenizi aftin. } \\
\text { here we see a witch and a dancer. the witch is combing herPRON } \\
\text { 'Here we see a witch and a dancer. The witch is combing her.' }\end{array}$ & PronTest \\
\hline $\begin{array}{l}\text { Edo vlepume ena baba ki ena papu. O babas forai paputsia. } \\
\text { here we see a dad and a grandpa. the dad is wearing shoes } \\
\text { 'Here we see a dad and a grandpa. The dad is wearing shoes.' }\end{array}$ & NounControl \\
\hline $\begin{array}{l}\text { Edo vlepume mia kamilopardali ke mia ajelada. I kamilopardali glifi ton eafto tis. } \\
\text { here we see a giraffe and a cow. the giraffe is licking herself } \\
\text { 'Here we see a giraffe and a cow. The giraffe is licking itself.' }\end{array}$ & ReflTest \\
\hline $\begin{array}{l}\text { Edo vlepume mia mama ke mia jaja. I mama pleni ton eafto tis. } \\
\text { here we see a mom and a grandma. the mom is washing herself } \\
\text { 'Here we see a mom and a grandma. The mom is washing herself.' }\end{array}$ & ReflTest \\
\hline $\begin{array}{l}\text { Edo vlepume mia majisa ke mia horeftria. I magisa tin chtenizi. } \\
\text { here we see a witch and a dancer. the witch herCL is combing } \\
\text { 'Here we see a witch and a dancer. The witch is combing her.' }\end{array}$ & ClControl \\
\hline $\begin{array}{l}\text { Edo vlepume ena prigipa ki enan andra. O andras stekete. } \\
\text { here we see a prince and a man. the man is standing } \\
\text { 'Here we see a prince and a man. The man is standing.' }\end{array}$ & NounControl \\
\hline $\begin{array}{l}\text { Edo vlepume enan vasilia ki ena mago. O valisias pleni ton eafto tu. } \\
\text { here we see a king and a wizard. the king is washing himself } \\
\text { 'Here we see a king and a wizard. The king is washing himself.' }\end{array}$ & ReflControl \\
\hline Edo vlepume mia mama ke mia jaja. I mama forai kapelo. & NounTest \\
\hline
\end{tabular}




\begin{tabular}{|c|c|}
\hline $\begin{array}{l}\text { here we see a mom and a grandma. the mom is wearing a hat } \\
\text { 'Here we see a mom and a grandma. The mom is wearing a hat.' }\end{array}$ & \\
\hline $\begin{array}{l}\text { Edo vlepume ena nano ki enan prigipa. O nanos ton chtenizi. } \\
\text { here we see a dwarf and a prince. the dwarf himCL is combing } \\
\text { 'Here we see a dwarf and a prince. The dwarf is combing him.' }\end{array}$ & ClTest \\
\hline $\begin{array}{l}\text { Edo vlepume mia neraida ke mia prigipisa. I neraida kratai ti miti tis. } \\
\text { here we see a fairy and a princess. the fairy is holding her nose } \\
\text { 'Here we see a fairy and a princess. The fairy is holding her nose.' }\end{array}$ & NounTest \\
\hline $\begin{array}{l}\text { Edo vlepume ena kloun ki ena papu. O kloun vafi ton eafto tu. } \\
\text { here we see a clown and a grandpa. the clown is painting himself } \\
\text { 'Here we see a clown and a grandpa. The clown is painting himself.' }\end{array}$ & ReflControl \\
\hline $\begin{array}{l}\text { Edo vlepume ena vasilia ki ena mago. O vasilias grafi ston ipologisti. } \\
\text { here we see a kind and a wizard. the king is writing at the computer } \\
\text { 'Here we see a kind and a wizard. The king is writing at the computer.' }\end{array}$ & NounTest \\
\hline $\begin{array}{l}\text { Edo vlepume mia magisa ke mia horeftria. I magisa chtenizi ton eafto tis. } \\
\text { here we see a witch and a dancer. the witch is combing herself } \\
\text { 'Here we see a witch and a dancer. The witch is combing herself.' }\end{array}$ & ReflTest \\
\hline $\begin{array}{l}\text { Edo vlepume ena kloun ki ena papu. O kloun ton vafi. } \\
\text { here we see a clown and a grandpa. the clown himCL is painting } \\
\text { 'Here we see a clown and a grandpa. The clown is painting him.' }\end{array}$ & ClControl \\
\hline $\begin{array}{l}\text { Edo vlepume mia vasilisa ke mia horeftria. I vasilisa pezi kithara. } \\
\text { here we see a queen and a dancer. the queen is playing guitar } \\
\text { 'Here we see a queen and a dancer. The queen is playing the guitar.' }\end{array}$ & NounControl \\
\hline $\begin{array}{l}\text { Edo vlepume ena skilo ki enan elefanda. O skilos glifi afton. } \\
\text { here we see a dog and an elephant. the dog is licking himPRON } \\
\text { 'Here we see a dog and an elephant. The dog is licking it/him'. }\end{array}$ & PronTest \\
\hline $\begin{array}{l}\text { Edo vlepume mia kamilopardali ke mia ajelada. I kamilopardali ti glifi. } \\
\text { here we see a giraffe and a cow. the giraffe herCL is licking } \\
\text { 'Here we see a giraffe and a cow. The giraffe is licking it/her.' }\end{array}$ & ClTest \\
\hline $\begin{array}{l}\text { Edo vlepume ana papu ki ena pirosvesti. O pirosvestis forai kranos. } \\
\text { here we see a grandpa and a fireman. the fireman is wearing helmet } \\
\text { 'Here we see a grandpa and a fireman. The fireman is wearing a helmet.' }\end{array}$ & NounControl \\
\hline Edo vlepume mia jaja ke mia horeftria. I jaja diavazi efimerida. & NounTest \\
\hline
\end{tabular}




\begin{tabular}{|c|c|}
\hline $\begin{array}{l}\text { here we see a grandma and a dancer. the grandma is reading newspaper } \\
\text { 'Here we see a grandma and a dancer. The grandma is reading a newspaper.' }\end{array}$ & \\
\hline $\begin{array}{l}\text { Edo vlepume mia prigipisa ke mia magisa. I prigipisa vafi aftin. } \\
\text { here we see a princess and a witch. The princess is painting herPRON } \\
\text { 'Here we see a princess and a witch. The princess is painting her.' }\end{array}$ & PronTest \\
\hline $\begin{array}{l}\text { Edo vlepume ena vasilia ki ena mago. O vasilias pleni afton. } \\
\text { here we see a king and a wizard. the king is washing himPRON } \\
\text { 'Here we see a king and a wizard. The king is washing him.' }\end{array}$ & PronTest \\
\hline $\begin{array}{l}\text { Edo vlepume mia mama ke mia jaja. I mama tin pleni. } \\
\text { here we see a mom and a grandma. The mom herCL is washing } \\
\text { 'Here we see a mom and a grandma. Mom is washing her. }\end{array}$ & ClControl \\
\hline $\begin{array}{l}\text { Edo vlepume ena mago ki ena vasilia. O magos ton zografizi. } \\
\text { here we see a wizard and a king. the wizard himCL is drawing } \\
\text { 'Here we see a wizard and a king, The wizard is drawing him.' }\end{array}$ & NounControl \\
\hline $\begin{array}{l}\text { Edo vlepume mia prigipisa ke mia magisa. I prigipisa ti vafi. } \\
\text { here we see a princess and a witch. the princess herCL is painting } \\
\text { 'Here we see a princess and a witch. The princess is painting her.' }\end{array}$ & ClTest \\
\hline $\begin{array}{l}\text { Edo vlepume ena kloun ki ena papu. O kloun vafi afton. } \\
\text { here we see a clown and a grandpa. the clown is painting himPRON } \\
\text { 'Here we see a clown and a grandpa. The clown is painting him'. }\end{array}$ & PronControl \\
\hline $\begin{array}{l}\text { Edo vlepume ena nano ki enan prigipa. O nanos chtenizi ton eafto tu. } \\
\text { here we see a dwarf and a prince. the dwarf is combing himself } \\
\text { 'Here we see a dwarf and a prince. The dwarf is combing himself.' }\end{array}$ & ReflControl \\
\hline
\end{tabular}




\section{Appendix 2}

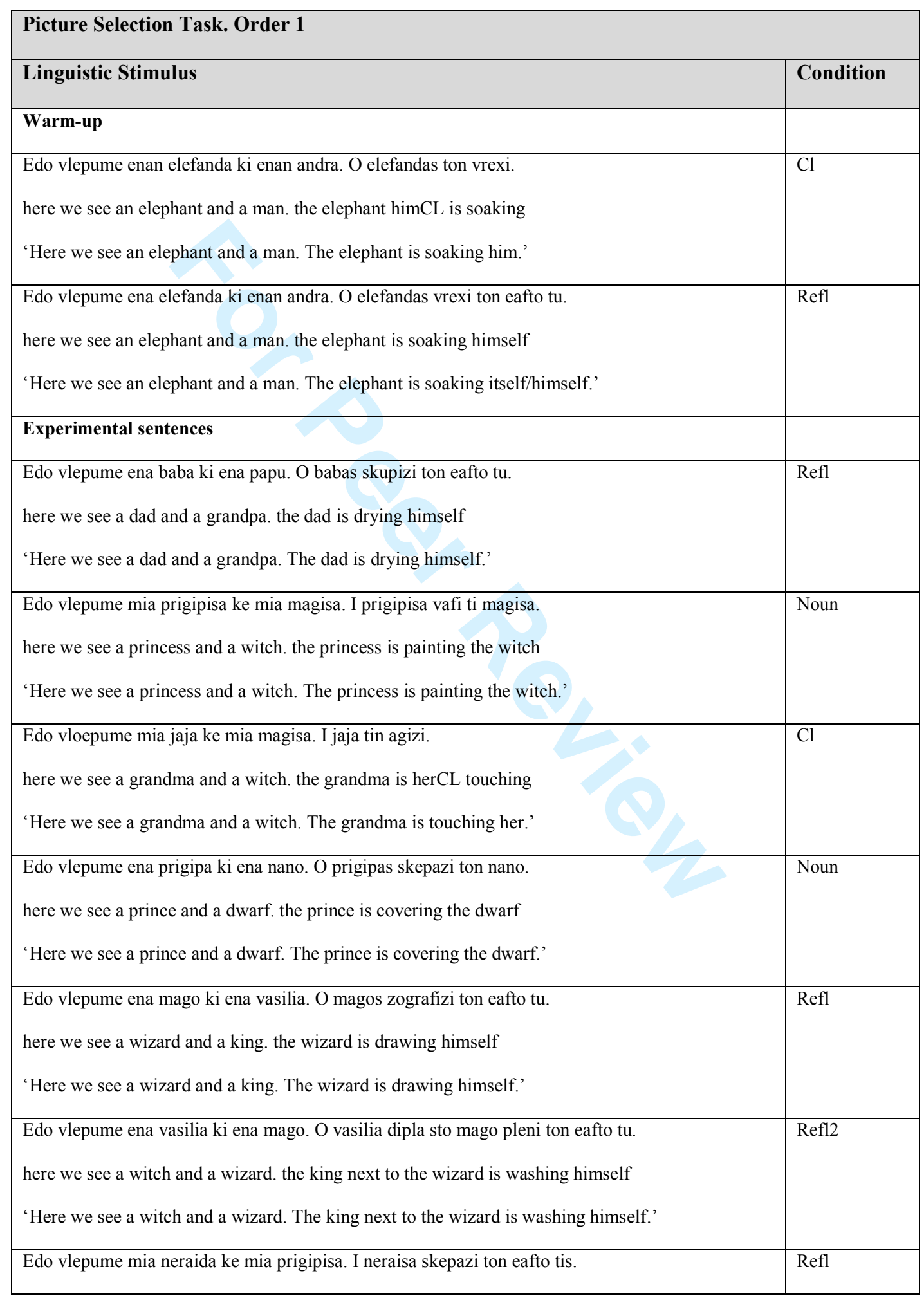




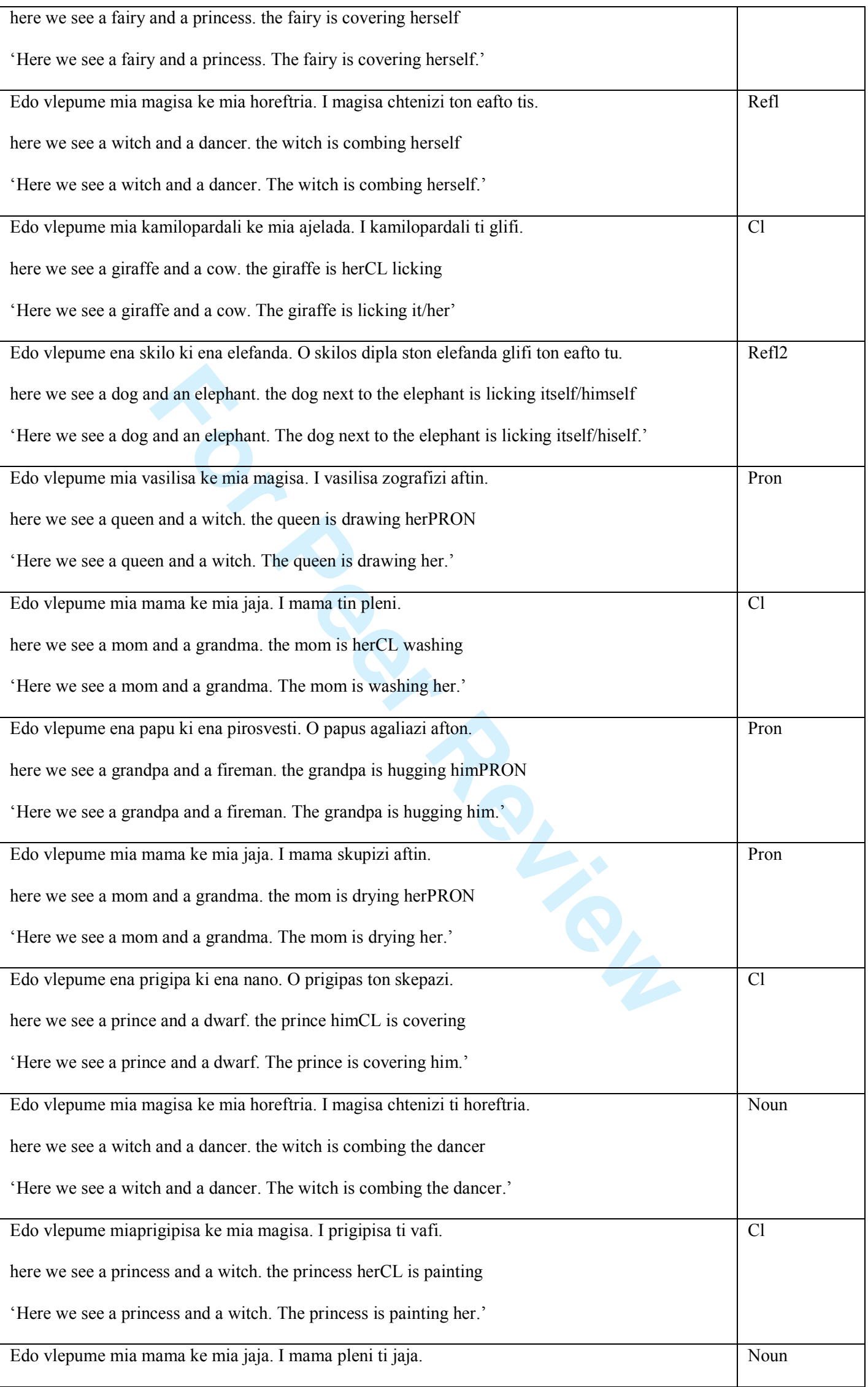




\begin{tabular}{|c|c|}
\hline $\begin{array}{l}\text { here we see a mom and a grandma. the mom is washing the grandma } \\
\text { 'Here we see a mom and a grandma. The mom is washing the grandma.' }\end{array}$ & \\
\hline $\begin{array}{l}\text { Edo vlepume ena prigipa ki ena nano. O prigipas dipla sto nano skepazi ton eafto tu. } \\
\text { here we see a prince and a dwarf. the prince next to the dwarf is covering himself } \\
\text { 'Here we see a prince and a dwarf. The prince next to the dwarf is covering himself.' }\end{array}$ & Refl2 \\
\hline $\begin{array}{l}\text { Edo vlepume mia jaja ke mia horeftria. I jaja agkaliazi ton eafto tis. } \\
\text { here we see a grandma and a dancer. the grandma is covering herself } \\
\text { 'Here we see a grandma and a dancer. The grandma is covering herself.' }\end{array}$ & Refl \\
\hline $\begin{array}{l}\text { Edo vlepume ena baba ki ena papu. O babas ton skupizi. } \\
\text { here we see a dad and a grandpa. the dad himCL is drying } \\
\text { 'Here we see a dad and a grandpa. The dad is drying him.' }\end{array}$ & $\mathrm{Cl}$ \\
\hline $\begin{array}{l}\text { Edo vlepume mia neraida ke mia prigipisa. I neraida skepazi aftin. } \\
\text { here we see a fairy and a princess. the fairy is covering herPRON } \\
\text { 'Here we see a fairy and a princess. The fairy is covering her.' }\end{array}$ & Pron \\
\hline $\begin{array}{l}\text { Edo vlepume mia magisa ke mia horeftria. I magisa ti htenizi. } \\
\text { here we see a witch and a dancer. the witch herCL is combing } \\
\text { 'Here we see a witch and a dancer. The witch is combing her.' }\end{array}$ & $\mathrm{Cl}$ \\
\hline $\begin{array}{l}\text { Edo vlepume ena papu ki ena pirosvesti. O papus ton agaliazi. } \\
\text { here we see a grandpa and a fireman. the grandpa himCL is hugging } \\
\text { 'Here we see a grandpa and a fireman. The grandpa is hugging him.' }\end{array}$ & $\mathrm{Cl}$ \\
\hline $\begin{array}{l}\text { Edo vlepume ena skilo ki ena elefanda. O skilos glifi ton elefanda. } \\
\text { here we see a dog and an elephant. the dog is licking the elephant } \\
\text { 'Here we see a dog and an elephant. The dog is licking the elephant.' }\end{array}$ & Noun \\
\hline $\begin{array}{l}\text { Edo vlepume ena kloun ki ena papu. O kloun vafi ton eafto tu. } \\
\text { here we see a clown and a grandpa. the clown is painting himself } \\
\text { 'Here we see a clown and a grandpa. The clown is painting himself.' }\end{array}$ & Refl \\
\hline $\begin{array}{l}\text { Edo vlepume mia neraisa ke mia vasilisa. I neradia agizi aftin. } \\
\text { here we see a fairy and a queen. the fairy is touching herPRON } \\
\text { 'Here we see a fairy and a queen. The fairy is touching her.' }\end{array}$ & Pron \\
\hline $\begin{array}{l}\text { Edo vlepume ena nano ki ena prigipa. O nanos dipla ston prigipa htenizi ton eafto tu. } \\
\text { here we see a dwarf and a prince. the dwarf next to the prince is combing himself } \\
\text { 'Here we see a dwarf and a prince. The dwarf next to the prince is combing himself'. }\end{array}$ & Refl2 \\
\hline Edo vlepume mia kamilopardali ke mia ajelada. I kamilopardali glifi aftin. & Pron \\
\hline
\end{tabular}


here we see a giraffe and a cow. the giraffe is licking herPRON

'Here we see a giraffe and a cow. The giraffe is licking it/her.'

Edo vlepume ena mago ki ena vasilia. O magos zografizi to vasilia.

here we see a wizard and a king. the wizard is painting the king

'Here we see a wizard and a king. The wizard is painting the king.'

Edo vlepume ena baba ki ena papu. O babas skupizi ton papu.

here we see a dad and a grandpa. the dad is drying the grandpa

'Here we see a dad and a grandpa. The dad is drying the grandpa.'

Edo vlepume mia neraida ke mia vasilisa. I neraida agizi ton eafto tis.

here we see a fairy and a queen. the fairy is touching herself

'Here we see a fairy and a queen. The fairy is touching herself.'

Edo vlepume ena kloun ki ena papu. O kloun vafi afton.

here we see a clown and a grandpa. the clown is painting himPRON

'Here we see a clown and a grandpa. The clown is painting him.'

Edo vlepume mia jaja ke mia horeftria. I jaja dipla sti horeftria agaliazi ton eafto tis.

here we see a grandma and a dancer. the grandma next to the dancer is hugging herself

'Here we see a grandma and a dancer. The grandma next to the dancer is hugging herself.'

Edo vlepume mia vasilisa ke mia magisa. I vasilisa dipla sti magisa zografizi ton eafto tis.

here we see a queen and a witch. the queen next to the witch is drawing herself

'Here we see a queen and a witch. The queen next to the witch is drawing herself.'

Edo vlepume mia mama ke mia jaja, I mama dipla sti jaja skupizi ton eafto tis.

here we see a mom and a grandma. the mom next to the grandma is drying herself

'Here we see a mom and a grandma. The mom next to the grandma is drying herself.'

Edo vlepume ena nano ki ena prigipa. O nanos htenizi afton.

Pron

here we see a dwarf and a prince. the dwarf is combing himPRON

'Here we see a dwarf and a prince. The dwarf is combing him.'

Edo vlepume ena skilo ki ena elefanda. O skilos glifi ton eafto tu.

here we see a dog and an elephant. the dog is licking himself

'Here we see a dog and an elephant. The dog is licking itself/himself.'

Edo vlepume mia mama ke mia jaja. I mama pleni aftin.

Pron

here we see a mom and a grandma. the mom is washing herPRON

'Here we see a mom and a grandma. The mom is washing her.'

Edo vlepume ena papu ki ena pirosvesti. O papus agaliazi ton pirosvesti. 


\begin{tabular}{|c|c|}
\hline $\begin{array}{l}\text { here we see a grandpa and a fireman. The grandpa is hugging the fireman } \\
\text { 'Here we see a grandpa and a fireman. Grandpa is hugging the fireman.' }\end{array}$ & \\
\hline $\begin{array}{l}\text { Edo vlepume mia jaja ke mia magisa. I jaja dipla sti magisa agizi ton eafto tis. } \\
\text { here we see a grandma and a witch. the grandma next to the witch is touching herself } \\
\text { 'Here we see a grandma and a witch. The grandma next to the witch is touching herself.' }\end{array}$ & Refl2 \\
\hline $\begin{array}{l}\text { Edo vlepume ena vasilia ki ena mago. O vasilias pleni ton eafto tu. } \\
\text { here we see a king and a wizard. the king is washing himself } \\
\text { 'Here we see a king and a wizard. The king is washing himself.' }\end{array}$ & Refl \\
\hline $\begin{array}{l}\text { Edo vlepume mia neraida ke mia vasilisa. I neraisa agizi ti vasilisa. } \\
\text { here we see a fairy and a queen. the fairy is touching the queen } \\
\text { 'Here we see a fairy and a queen. The fairy is touching the queen.' }\end{array}$ & Noun \\
\hline $\begin{array}{l}\text { Edo vlepume mia prigipisa ke mia magisa. I prigipisa dipla sti magisa vafi ton eafto tis. } \\
\text { here we see a princess and a witch. the princess next to the witch is painting herself } \\
\text { 'Here we see a princess and a witch. The princess next to the witch is painting herself.' }\end{array}$ & Refl2 \\
\hline $\begin{array}{l}\text { Edo vlepume ena mago ki ena vasilia. O magos ton zografizi. } \\
\text { here we see a wizard and a king. the wizard himCL is drawing } \\
\text { 'Here we see a wizard and a king. The wizard is drawing him.' }\end{array}$ & $\mathrm{Cl}$ \\
\hline
\end{tabular}

